\title{
Horticultural Science at the University of Guelph: New Building
}

On 17 Sept. 1991, the Univ. of Guelph officially opened a new building (see front cover) to house the Depts. of Horticultural Science and Environmental Biology. It is known as the Bovey Building, named after the former University Chancellor, Edmund C. Bovey. The $\$ 30$ million complex was funded by an $\$ 18.5$ million contribution from the Ontario Ministry of Colleges and Universities and by private donations through the university's capital campaign. The largest private-sector contribution was $\$ 1$ million from the Ontario Fruit and Vegetable Growers' Assn. The 16,000 $\mathrm{m}^{2}$ complex provides state-of-the-art teaching, research, greenhouse, and office facilities for the two departments.

\section{History}

Horticulture has been apart of the Ontario Agricultural College (now the Univ. of Guelph) since its beginning in 1874. The Dept. of Horticultural Science (changed from Horticulture in 1968) was established to provide teaching, research, and extension for the horticultural industry. The Univ. of Guelph serves as the only horticultural science teaching institution for undergraduate and graduate study in Ontario and is the major horticultural science teaching institution in Canada.

Moving into the new building has made academic and administrative history for horticulture, because, for almost 100 years, the department has enjoyed a building to itself, dedicated to all of those activities that can be included in horticulture. The first building used exclusively by the department was constructed in 1892. The second building and greenhouses, which have just been vacated, were built in 1929-31. In moving to the new shared building the department may lose

Received for publication 31 Jan. 1992. Accepted for publication 7 Feb. 1992. The cost of publish ing this paper was defrayed in part by the payment of page charges. Under postal regulations, this paper therefore must be hereby marked advertisement to indicate this fact.

Front cover: Univ. of Guelph's new Bovey Building housing the Depts. of Horticulture and Environmental Biology. Photograph by Don Hamilton. some of its identity and central campus location, but may well gain in opportunities for cooperative, coordinated, and additive activities with the Dept. of Environmental Biology.

\section{Teaching}

Faculty in horticultural science at Guelph teach students at three levels-diploma, undergraduate, and graduate. The Diploma in Agriculture (Horticulture) is a 2-year program that provides an education midway between that of a professional and skilled laborer. The course of studies provides knowledge of the techniques and technologies currently in use in the horticultural industry, such that the development of the principles on which application is based enables students to understand the basic reasons for recommended practices. Each year -60 students graduate from the diploma program and find employment in garden centers, nurseries, golf courses, greenhouse operations, and various allied trades.

The honors baccalaureate 4-year program provides a fundamental education in the scientific disciplines that constitute horticultural science. The program of studies expands on the basic principles of plant sciences by providing knowledge of the current technologies in horticultural science, stressing their current and/or potential use in the horticultural industry, and enables the department to graduate competent professionals in horticulture who are flexible and able to think, reason, and communicate.

Over each of the last 5 years, an average of 30 students have graduated with undergraduate degrees and found employment as managers in various horticultural trades, such as public or private horticultural advisors, and on the family farm. In the diploma and undergraduate programs a co-op option is offered that allows students to work in organized, paid, 3-to 4-month placements in the horticultural industry. In each program this adds $\approx 1$ year, but students find these experiences invaluable, particularly in regard to permanent employment.

The undergraduate program has undergone considerable change in the last 5 years, with the result that students can choose one of two options, or streams. The primary pro- gram leads to a degree in horticultural science and business. Some of the basic science courses in the earlier BSc (Agr.) program have been replaced with courses in economics and business. Students who contemplate careers in more basic sciences allied to horticulture can choose plant biology with an emphasis in either horticultural science or urban horticulture and environment management, or plant biotechnology.

Complementing teaching in horticultural science at Guelph is an array of programs in other departments and schools, many of which originated in, and still have strong ties with, horticultural science. For instance, in 1965, landscape architects left the "mother" department to form a school of landscape architecture that graduates students with BLA and MLA degrees. Another example is independent study in the School of Continuing Education, which offers correspondence courses in many aspects of horticulture. In 1991,61 adults earned a diploma in horticulture from this program; half of the graduating class live and work in Ontario. The rest live across Canada, the United States, and in Bermuda.

The graduate program produces highly competent scientists within established and new research programs to meet Canada's current and future needs for trained professional scientists in horticulture. There are usually 40 to 50 graduate students, and in keeping with the Univ. of Guelph's large international commitment, about one-fourth of these students will be from outside Canada. Guelph MSC and PhD horticultural science graduates can be found in Canadian universities, with Agriculture Canada, provincial governments, the horticultural industry, and similar organizations around the world.

\section{Research}

The Horticultural Science Dept. provides research expertise in many areas. Food production receives emphasis, balanced and complemented by major programs in the production of ornamental plants and turf. Breeding programs for improved cultivars of fruit, vegetables, and ornamentals are ongoing, well established, and now are expedited by development of tissue culture and biotechnology techniques. New cultivars are evaluated under Ontario conditions to determine their suitability for commercial production and their acceptance by consumers.

Considerable research effort is devoted to improving management practices for a wide range of crops and evaluating environmental effects on various species, and the postharvest physiology and storage of horticultural commodities.

The nature of horticulture will change dramatically in the next two to three decades as it confronts increased demands for food

(continued on inside back cover) 
(continued from inside front cover)

and acceptable standards of quality of life and environment. New technologies are emerging that will assist in meeting these challenges. Our genetic engineering work will enable the rapid transfer of genes among organisms that are separated by reproductive barriers. The power of $\mathrm{N}$ fixation may be transferred to nonlegumes. Resistance to herbicides, diseases, pests, and environmental stresses may be transferred within and across species boundaries. Computers will be used more widely to interpret the information and make recommendations. Greater use of controlled environments for the production of food is likely. These and other changes not yet conceived will shortly be common realities. The Dept. of Horticultural Science with its new facilities, new broad-based but focused educational programs, a dynamic faculty and staff, and eager students will play a pivotal role in discovering new technology and adapting it to improve the food and the environment offered to the consumer.

John T.A. Proctor

DenNIS P. Murr

and E.C. (SAM) LOUGHeEd Dept. of Horticultural Science

University of Guelph Guelph, Ont. N1G 2W1

Canada 